\title{
Comparison of Body Perceptions of Athletes in the Team and Individual Branches*
}

\author{
Ünsal Tazegül”, Özbay Güven \\ School of Physical Education and Sports, Mardin Artuklu University, Mardin, Turkey
}

Copyright $\mathrm{O} 2018$ by authors, all rights reserved. Authors agree that this article remains permanently open access under the terms of the Creative Commons Attribution License 4.0 International License

\begin{abstract}
This study aims to the comparison of body image satisfaction levels of athletes in individual and team sports. The sample of the study was selected by 34 athletes engaged in athletics, 52 athletes engaged in boxing, 45 athletes engaged in wrestling, 37 athletes engaged in weightlifting, 36 athletes engaged in handball, 35 athletes engaged in rowing, 41 athletes engaged in taekwondo, 36 athletes engaged in swimming, 31 athletes engaged in water polo, 35 athletes engaged in volleyball and 42 athletes engaged in bodybuilding and all these athletes already ranked among the top three athletes in Turkish Championships. The scales were applied to athletes included in sample in 2017. In the study, "Body Image Scale" which was validated, trusted, and adapted to Turkish language by Hovardaoğlu (1986) was used as data collection tool. For analyses of data, Portable IBM SPSS Statistics v20 software package was used. Paired sample t-test and descriptive statistical analysis were applied in the analysis of the data. According to the statistical analysis results, it was determined that body image satisfaction level of athletes engaged in wrestling is higher than other athletes.
\end{abstract}

Keywords Body Perception, Team Sports and Individual Sports

\section{Introduction}

The concept of body image was first addressed in 1920 as a psychologic and sociologic concept by Paul Schilder. Studies before Schilder were usually limited to distorted body images which came out due to brain damage. Schilder defines body image as the own picture of a person shaped in his/her mind by him/her [1,2].

Body image distortion was first included in phantom organ fact report of a 16th century surgeon, Ambroise Pare. acar Head, a neurologist in 1920s, asserts the concept of body schema. Accordingly, body schema is a whole comprising of past lives which are organized mainly in emotional cortex and current sensations" [3].

Past experiences of a person take an important place in development of body image. Responses of a person to his/her own body in the past and reactions of the surrounding society regarding his/her body, affect body image development of a person [4]. Body image that is usually perceived positively may cause significant effects on self-esteem and self-confidence of an individual [5].

In many studies, it has been shown that sport contributes to individual positive character development and contributes to the development of body sensation [6]

Sports may influence body image among women in many ways. Competitive environment embodied in sports may promote athletes for having a better body [7], moreover feeling of perfectionism which comes out in sports may also effect desire for having a beautiful body [8]. Hausenblas and Fallon finds in their study in 2006 that sports has a positive effect on body satisfaction

Today, people have better realized necessity of joining physical activities. Many people attend sport centers or exercise at home. People utilize methods such as acupuncture, surgical operation, medication, diet, physical activity and exercise in order to keep their body shapes or have ideal body sizes. Physical activity which is one of the ways followed for ideal body structure is a method many people have preferred in recent years. While people find an opportunity to have a new physical appearance through physical activities, with this new appearance they also have positive thoughts on physical fitness characteristics of their bodies. As a result of study conducted by Çok on adolescent sedentaries, it is found that teenagers who participate in physical activities are more satisfied with their bodies compared to those who do not participate. It has been put forward through studies that physical activity has a positive effect on body image and that people who participate in physical activities feel less anxious compared to those who do not join physical activity, when their bodies are assessed by other people, as well [4]. It is stated 
that Swedish young girls and boys who aim at athletics focus on their bodies and body functions and have positive thinking about their bodies. It has been revealed in many studies that sports contribute to positive character development and body image development of a person [6].

The aim of this study is to compare the body sensory levels of the athletes in the team and individual fields.

\section{The Method}

In this study, quantitative method of research was used. The quantitative method of research is defined as a method of research that can be observed, measured, and numerically expressed by objectifying phenomena and events. The main aim in quantitative studies is to examine the social behaviors of people through observation, experiment, and test, and to quantify them numerically.

\subsection{Study Group}

The study group consists of 34 athletes in the branch of athletics, 52 athletes in the boxing branch, 45 athletes in the wrestling branch, 37 athletes in the weightlifting branch, 36 athletes in the handball branch, 35 athletes in the rowing branch, 41 athletes in the taekwondo branch, 36 athletes in the swimming branch, 31 athletes in the water polo branch, 35 athletes in the volleyball branch and 42 athletes in the bodybuilding branch, who rank among the top three within the categories of Adults and Youth in Turkey. 424 male athletes participated in the study as a total.

\subsection{Data Collection Tools}

\subsubsection{Body Perception Scale}

The Body Image Perception Scale (Annex-6), originally titled as "Body-Cathexis Scale" (BCS), was developed by Secard and Jurard in 1953 and is a scale that measures an individual's satisfaction for 40 separate body parts or functions. The scale was translated into Turkish by Hovardaoğlu in 1986 and according to the study carried out with university students, the split-half reliability coefficient was found as 75 , item test correlations were found between the $\mathrm{r}=.45$ and $\mathrm{r}=.89$ and reliability coefficient was found as $r=.91$. The type of scale used in Turkey is a measurement tool consisting of 5-point Likert-type scale with 40 items (1=Strongly agree, 2= Agree, 3= Neutral, 4= Disagree, 5= Strongly disagree). The most positive expression is 1 point and the most negative one is 5 points. Accordingly, the lowest possible total score is 40 and the highest total score is 200 . The increase in the total score obtained from the scale indicates that the satisfaction of the person's body parts or function decreases, while a decrease in scores indicates an increase in satisfaction [As cited by 9]. In our study, the reliability coefficient was determined as 0.913 .

\subsection{Analysis of Data}

SPSS 20 was used for analyzing the data in this research. "Kolmogorov-Smirnov" test was applied to determine that the data had a normal distribution while "Anova-Homogeneity of variance" test was applied to determine its homogeneity and it was found that the data was homogeneous, with a normal distribution. Descriptive statistics and independent sample $t$ test were used in the analysis of data.

\section{Findings}

Table 1. Descriptive statistical findings showing the body perception score of the athletes.

\begin{tabular}{ccc}
\hline Sports branches & M & SD \\
\hline Athleticism & 79.0882 & 14.88210 \\
\hline Boxing & 80.1923 & 17.09952 \\
\hline Wrestling & 68.5556 & 15.56008 \\
\hline Weight lifting & 72.2162 & 27.07719 \\
\hline Handball & 75.9722 & 11.18030 \\
\hline Rowing & 81.2857 & 11.87080 \\
\hline Water ball & 76.1290 & 5.86937 \\
\hline Taekwondo & 77.0976 & 14.00679 \\
\hline Volleyball & 88.6857 & 4.68898 \\
\hline Body building & 74.0000 & 15.15610 \\
\hline Swimming & 79.7500 & 3.65181 \\
\hline
\end{tabular}

According to Table 1, it has been determined that the athletes in the volleyball branch (88.6857) rank first with the body perception score and the athletes in the wrestling branch (68.5556) rank the last with the body perception score.

Table 2. Comparison of body perception scores of athletes in the team and individual branches

\begin{tabular}{ccccc}
\hline Sports Type & $\mathrm{n}$ & $\mathrm{M}$ & $\mathrm{SD}$ & $\mathrm{p}$ \\
\hline Individual & 252 & 75.8049 & 16.93004 & \\
\hline Team & 172 & 80.5177 & 29.50517 & 0 \\
\hline
\end{tabular}

According to Table 2, there is a statistically significant difference between the body perceptions of team and individual athletes $(\mathrm{p}<0.05)$.

\section{Discussion and Results}

As a result of the descriptive statistical analysis, it was determined that the level of body satisfaction of the athletes in the wrestling branch was higher than the other athletes participated in this study. When these results are evaluated according to the body perception scale, it is concluded that 
the athletes in the wrestling branch are more satisfied with their bodies and parts of their bodies. It can be said that the athletes in the individual branches are more pleased with their bodies than the athletes in the team sports because of the fact that they have more remarkable and developed muscle mass. In a research, examining the muscle and body images of males, carried out by Pickett, Lewis and Cash in [10], they determined that elite and amateur bodybuilders are more likely to have higher appearance evaluation scores than the other active individuals.

High body pleasure is associated with good physical performance, and physically active men and women are more pleased than their bodies. It can be considered that they are more successful in athletes who are generally pleased with their bodies, because the athlete who is pleased with his / her body may have a better inner motivation. When the wrestling branch is examined in general, it is seen that the wrestling individuals have an aesthetic body and are making physical movements that are difficult to do. Making wrestlers' movements can affect body senses positively.

As a result of the literature review, different studies supporting the data of this study have been found. Some of these studies are as follows:

In the study of Pavao of [11], it was determined that the attitude scores towards the bodies of the athletes in the wrestling branch were higher than those in the football, basketball and baseball branches. Taub and Blinde in [12], found that the athletes in the softball branch had a higher level of body dissatisfaction than the athletes in the volleyball and basketball branch. In the study of Çağlar in [13], the body attractiveness level of male athletes in the handball category was determined as 17.08 , while their physical competence level was determined as 17.49. Sundot-Borgen [14] stated that skinny athletes had greater body dissatisfaction than those who are not skinny. In the study of Aşç1 in [15], the body dissatisfaction level of young male national basketball players was determined as 3.89. Parks and Read [16] found that the body image of the athletes in the football branch was higher than the athletes in the running branch. A statistically significant difference was determined as a result of the comparison of the body perception made between individual and team sport athletes. It was established that the level of body perception of the athletes in the individual branch was higher than the level of the athletes in the team branch. In the study of Frost and McKelvie carried out in [17], It was found that individuals with low level of physical exercise had higher body perception scores than those with high levels of exercise. In addition, they determined a relationship between body perception and self-esteem in their study. In the study of Tazegül [18], he determined the body admiration scores of the tennis players as 40.9808 while he established a positive relationship between the body admiration scores and positive thinking scores of the tennis players. In his study Tazegül [19], he detected a positive correlation between the body admiration scores and conduct of life scores of the tennis players. In the study of Kara and Tazegül in [20], they identified body admiration scores of the disabled athletes as 38.906. Tazegül and Geçer [21], conducted a study on the development of an athletic vigilance scale. At the end of the study, it was determined that arm and chest dimension 7.5439, shoulder, back and hip area dimension 12.2281, skin color and general physical structure dimension 9.0526, abdominal region and legs dimension 7.5175 , total body perception 36.3421. In the study of Tazegül in 2016c[22], he determined the body perception of bodybuilders competing in the category of athletes weigh a maximum of $75 \mathrm{~kg}$ as 88.6667 , bodybuilders competing in the category of athletes weigh a maximum of $80 \mathrm{~kg}$ as 88.4400 , bodybuilders competing in the category of athletes weigh a maximum of $85 \mathrm{~kg}$ as 80.7500 , bodybuilders competing in the category of athletes weigh a maximum of $70 \mathrm{~kg}$ as 80.200 , bodybuilders competing in the category of athletes weigh a maximum of $60 \mathrm{~kg}$ as 78.2917 , bodybuilders competing in the category of athletes weigh a maximum of $65 \mathrm{~kg}$ as 77.2162 , bodybuilders competing in the category of athletes weigh a maximum of $90 \mathrm{~kg}$ as 73.0000 .

As a consequence, it was determined that the body satisfaction level of the athletes in the individual branch was better. It is thought that the athletes in the individual branches have an aesthetic and proportional muscle appearance, which has an influence on this situation.

\section{REFERENCES}

[1] Polat A. (2007). Düzce ilindeki hemodiyaliz hastalarının beden imaj1 ve benlik saygısı düzeylerinin belirlenmesi. Yayınlanmış Yüksek Lisans Tezi, Abant İzzet Baysal Üniversitesi Sağlık Bilimleri Enstitüsü, Düzce.

[2] Dunham, J.M. (2002).Perfectionism and Attitudinal Body Image in Developmental, High Performance, and Elite Figure Skaters. A thesis submitted to the Faculty of Graduate Studies and Research in partial fulfillment of the requirements for the degree of Master of Arts, University of Alberta, Department of Physical Education and Recreation.

[3] Doğan O \& Doğan S. (1992). Çok yönlü beden-self ilişkileri ölçeği el kitabı. Cumhuriyet Üniversitesi Tıp Fakültesi Basımevi, Sivas.

[4] Acar, T.Ö. (2010).Kocaeli Üniversitesi Beden Eğitimi Yüksekokulu ve Mimarlık-Mühendislik Fakültesi öğrencilerinde beden algısı ve iyilik halinin beden kitle indeksi ve vücut yağı dağılımı ile ilgisi, Uzmanlık Tezi, Kocaeli Üniversitesi Tıp Fakültesi, Kocaeli.

[5] Şanlı, T. (1991). Hemşirelikte kişilerarası ilişsiler. Ankara: AÖF Yayınları, No: 226.

[6] Brettschneider, W \& Heim, R. (1997). Identity, Sport, and Youth Development. In The Physical Self: From Motivation to Well-Being (ed. K. Fox, 205-227), Human Kinetics Publishing. 
[7] Striegel-Moore, R. H., Silberstein, L. R \& Rodin, J. (1986). Toward an understanding of risk factors for bulimia. American Psychologist, 41, 246-263.

[8] Fulkerson, J. A., Keel, P. K., Leon, G. R \& Dorr, T. (1999). Eating-disordered behaviors and personality characteristics of high school athletes and nonathletes. International Journal of Eating Disorders, 26, 73-79.

[9] Kundakc1, A.H. (2005). Üniversite öğrencilerinin yeme tutumlar1, benlik algıs1, vücut algıs1 ve stres belirtileri açısından karşılaştırılması, Yüksek Lisans Tezi, Ankara Üniversitesi, Sosyal Bilimler Enstitüsü, Ankara.

[10] Pickett, T. C., Lewis, R. J., and Cash, T. F. (2005). Men, muscles, and body image: comparisons of competitive bodybuilders, weight trainers, and athletically active controls. British Journal of Sports Medicine, 39(4), 217-222.

[11] Pavao, S.L. (2012) Differences in body dissatisfaction in male collegiate athletes, The Requirements for Departmental Honors in Psychology, Bridgewater State University.

[12] Taub, D.E., Blinde, E.M. (1992). Adolescence eating disorders among adolescent female athletes: Influence of athletic participation and sport team membership, Adolescence, 27(108), 833-848.

[13] Çağlar, E. (1999). Erkek hentbolcularda kendini fiziksel algılama ve kaygı düzeyi. Hacettepe Spor Bilimleri Dergisi, $(2,3,4), 33-44$.

[14] Sundgot-Borgen, J. (1994). Eating disorders in female athletes. Sports Medicine, 17, 176-188.
[15] Așçı, F. (1996) Genç erkek basketbolcuların kendini fiziksel algilama ve beden imgelerinde hoşnut olma profilleri. Spor Bilimleri Dergisi, 7(4), 13-20.

[16] Parks, P. S \& Read, M. H. (1997). Adolescent male athletes: Body image, diet, and exercise. Adolescence, 32, 593-602.

[17] Frost, J \& McKelvie, S.J. (2005).The relationship of self-esteem and body satisfaction to exercise activity for male and female elementary school, high school, and university students, Athletich Inpht, 7(4), 36-49.

[18] Tazegül, Ü. (2016a). Elit Düzeydeki Tenisçilerin Olumlu Düşünme Düzeyleri ile Bedenlerini Beğenmeleri Düzeyi Arasındaki İlişkinin Belirlenmesi, İnsan ve Toplum Bilimleri Araştırmaları Dergisi, 5; 8, 2907-2911.

[19] Tazegül, Ü. (2016b). Elit Düzeydeki Tenisçilerin Yaşama Bağlılık Düzeyleri İle Bedenlerini Beğenmeleri Arasındaki İlişkinin Belirlenmesi, Akademik Sosyal Araştırmalar Dergisi, 4, 32, 468-474.

[20] Kara, T \& Tazegül, Ü. (2016). Bedensel Engelli Sporcuların Kişilik Özellikleri İle Bedenlerini Beğenmeleri Arasındaki İlişkinin Belirlenmesi, The Journal of Academic Social Science, 4,: 38, s. 295-302

[21] Tazegül, Ü \& Geçer, A. (2016). Spora özgü sakatlık dönemi beden algısı ölçeğinin geliştirilmesi. The Journal of Academic Social Science Studies, 47, 511-518.

[22] Tazegül, Ü. (2016c). Elit düzeydeki vücut geliștirme sporcularının beden algılarını yarıştıkları kategorilere göre karşılaştırılması. Akademik Sosyal Araştırmalar Dergisi, 41, $29,34-42$.

* This article is derived from a $\mathrm{PhD}$ dissertation 